\title{
Hepatic stellate cells primed with cytokines upregulate inflammation in response to peptidoglycan or lipoteichoic acid
}

\author{
Yong-Han Paik ${ }^{1}$, Kwan Sik Lee ${ }^{1}$, Hyun Jin Lee ${ }^{1}$, Kyung Min Yang ${ }^{1}$, Se Jun Lee ${ }^{1}$, \\ Dong Ki Lee ${ }^{1}$, Kwang-Hyub Han ${ }^{1}$, Chae Yoon Chon ${ }^{1}$, Sang In Lee ${ }^{1}$, Young Myoung Moon ${ }^{1}$ \\ and David A Brenner ${ }^{2}$ \\ ${ }^{1}$ Department of Internal Medicine, Institute of Gastroenterology, Yonsei University College of Medicine, \\ Seoul, South Korea and ${ }^{2}$ Department of Medicine, Columbia University, College of Physicians and Surgeons, \\ New York, NY, USA
}

\begin{abstract}
Gram-positive bacterial products such as peptidoglycan (PGN) and lipoteichoic acid (LTA) are potent stimulators of innate inflammatory responses. We previously reported that lipopolysaccharide (LPS), a major biologically active agent of gram-negative bacteria, induces a proinflammatory response via the Toll-like receptor (TLR) 4 in hepatic stellate cells (HSCs). Here we investigated the mechanism of proinflammatory action by PGN and LTA in activated human HSCs. Following treatment with either TNF- $\alpha$ or IL-1 $\beta$, expression of TLR2 and CD14 was determined by real-time PCR and Western blotting. NF- $\kappa$ B activation was assessed by NF- $\kappa$ Bdriven luciferase assay and electrophoretic mobility shift assay. Interleukin-8 (IL-8) from culture supernatant was measured by ELISA. Activated human HSCs express TLR2 and CD14, which are receptors for PGN and LTA signaling. TNF- $\alpha$ and IL-1 $\beta$ significantly upregulated the expression of TLR2 mRNA and protein in HSCs. PGN and LTA induced NF- $\kappa$ B activation and stimulated production of IL-8 in HSCs. Pretreatment with TNF- $\alpha$ or IL-1 $\beta$ augmented NF- $\kappa$ B activation and IL-8 production in response to PGN or LTA. Both PGN- and LTA-induced NF$\kappa \mathrm{B}$ activation and IL-8 secretion were completely inhibited by anti-TLR2 blocking antibody (T2.5). These findings suggest that TNF- $\alpha$ or IL-1 $\beta$ primed HSCs enhance the production of IL-8 in response to PGN and LTA through augmentation of the TLR2 system.
\end{abstract}

Laboratory Investigation (2006) 86, 676-686. doi:10.1038/labinvest.3700422; published online 17 April 2006

Keywords: liver; fibrosis; cytokines; non-parenchymal cells; peptidoglycan; lipoteichoic acid

Chronic and repeated hepatic inflammation results in hepatic fibrosis and liver cirrhosis. A variety of liver injuries cause hepatocyte apoptosis, necrosis, and Kupffer cell activation, resulting in subsequent production of inflammatory cytokines. Various inflammatory cytokines activate and transform quiescent hepatic stellate cells (HSCs) into activated HSCs. Over-and-above their contractile properties, activated HSCs proliferate, migrate, secrete inflammatory cytokines and chemokines, and produce type I collagen. ${ }^{1}$ In addition, it has been reported that HSCs can uptake and present foreign antigens,

Correspondence: Professor KS Lee, MD, PhD, Department of Internal Medicine, Division of Gastroenterology, Yonsei University College of Medicine, Yongdong Severance Hospital, 146-92 Dogok-Dong, Kangnam-Gu, Seoul 135-720, South Korea.

E-mail: leeks519@yumc.yonsei.ac.kr

Received 1 October 2005; revised 7 March 2006; accepted 12 March 2006; published online 17 April 2006 and participate in the innate immune response in the liver. ${ }^{2}$

Toll-like receptors (TLRs) are type I integral membrane glycoproteins, which recognize pathogen-associated molecular patterns present in microbial components. ${ }^{3}$ So far, 13 members of the TLR family have been identified in mammals, and stimulation of different TLRs induces distinct patterns of gene expression, which leads to the activation of innate immunity. ${ }^{4}$ TLRs have a conserved cytoplasmic domain, Toll/IL-1R (TIR), and a variable extracellular domain which contains leucine-rich repeats that determine the responsiveness to a specific pathogen. ${ }^{5,6}$ TLR2 is located on the cell surface and is recruited to the phagosome after activation by its reactive ligand; this could be a lipoprotein, peptidoglycan, lipoteichoic acid, lipoarabinomannan, atypical liposaccharide, or heat-shock protein $70 .^{7-9}$ Thus, intracellular localization of TLR2 is a feature of exposure to its ligands. Activation of TLR2 leads to the recruitment of 
MyD88, an adaptor molecule, which then facilitates the association of IL-1 receptor-associated kinase (IRAK) 4 with MyD88. IRAK4 phosphorylates IRAK1, and activated IRAK1 autophosphorylates and enables TNF receptor-associated factor (TRAF) 6 to bind this complex. TRAF6 then disengages and translocates to the cytoplasm to activate the IKK (inhibitor of nuclear factor $\kappa \mathrm{B}$ kinase) complex and MAPKs resulting in the release of nuclear factor $\kappa \mathrm{B}$ $(\mathrm{NF}-\kappa \mathrm{B})$ and $\mathrm{c}$-Jun N-terminal kinase (JNK). ${ }^{3,10}$

In cirrhotic rats and human patients, intestinal bacterial overgrowth occurs, including not only gram-negative enteric bacteria but also gram-positive bacteria. ${ }^{11}$ Cirrhosis is also associated with increased permeability of the intestinal mucosal barrier and facilitated bacterial translocation into the portal vein. ${ }^{12,13}$ We previously reported that human HSCs expressed TLR4 and CD14, and showed a strong inflammatory reaction in response to lipopolysaccharide (LPS), a major cellular component of gram-negative bacteria. ${ }^{14}$ LPS-induced HSC and Kupffer cell activation is now regarded as an important mechanism of liver injury, especially in alcoholic liver diseases. ${ }^{14-16}$ Hence, there is a high likelihood that HSC will be exposed to bacterial products in the setting of chronic liver disease.

Riordan et $a l^{17}$ reported that the expression of TLR2 was upregulated in peripheral blood mononuclear cells (PBMCs) and was significantly correlated with serum TNF- $\alpha$ level in cirrhotic patients, suggesting a potential role of TLR2-mediated inflammation in the development of liver injury. In addition, Brun et $a l^{18}$ recently reported that lipoteichoic acid and $\mathrm{N}$-acetyl muramyl peptide induced TGF- $\beta$, IL-6, and MCP-1 in murine HSCs, suggesting the substantial role of gram-positive bacterial products in hepatic inflammation and fibrosis. However, the molecular mechanisms involved in the gram-positive bacterial product induction of inflammatory signaling in human HSCs are still unknown.

It has been reported that IFN- $\gamma$ or bacteria such as Propionibacterium acnes can enhance the LPSinduced inflammatory response by a selective priming of mononuclear phagocytes and fibroblasts. ${ }^{19-22}$ Those priming effects were mediated by an upregulation of TLR4 and/or other downstream signaling molecules including MD2, CD14, and MyD88. ${ }^{20-23}$ These results are intriguing with regard to hepatic injury and inflammation because many proinflammatory cytokines, such as TNF- $\alpha$, are upregulated in patients with liver cirrhosis and liver injury. ${ }^{24,25}$ Therefore, we hypothesized that the inflammatory reaction induced by the gram-positive bacterial cell wall components is also enhanced in an injured liver. In this study, we examined the inflammatory response induced by the gram-positive bacterial products, PGN and LTA, in activated human HSCs, and investigated further the underlying mechanism of cytokine-induced upregulation of PGN or LTA-induced inflammatory response.

\section{Materials and methods}

\section{Reagents}

PGN from Staphylococcus aureus, PGN from Bacillus subtilis, and LTA from Streptococcus pyogenes were purchased from Sigma (St Louis, MO). LPS levels were measured by Limulus Amebocyte lysate assay (Cambrex, Rutherford, NJ) and were less than $10 \mathrm{ng} / \mathrm{ml}$ of PGN or LTA stock solution. All stimulations were conducted in serum-free conditions to rule out possible contamination by LPS. LPS from Escherichia Coli serotype O127:B8 (phenol extracted and chromatographically purified by gel filtration, protein content $<1 \%$ ) was purchased from Sigma (St Louis, MO). Human recombinant TNF- $\alpha$ and IL- $1 \beta$ were purchased from R\&D Systems (Minneapolis, MN). Polymyxin B was purchased from Sigma. Mouse anti-human TLR2 blocking Ab (T2.5) and isotype $\operatorname{IgG}_{1} \mathrm{Ab}$ were obtained from eBioscience (San Diego, CA).

\section{Activated Human HSC Cell Line (hTERT) and Primary Human HSC Culture}

We used an immortal human HSC cell line established by functional expression of the telomerase catalytic subunit (human telomerase reverse transcriptase or hTERT) throughout most of the experiments because telomerase-positive HSCs exibited morphological and functional characteristics of activated human HSCs. This included the expression of smooth muscle $\alpha$-actin, glial fibrillary acidic protein (GFAP), and Type I collagen, as previously well characterized by Schnabl et al. ${ }^{26-28}$ Telomerasepositive HSCs were seeded on uncoated plastic tissue culture dishes and cultured in DMEM (Life Technologies, Grand Island, NY) supplemented with $10 \%$ heat inactivated FBS and standard antibiotics in a 95\% air and 5\% $\mathrm{CO}_{2}$ humidified atmosphere at $37^{\circ} \mathrm{C}$. For RT-PCR experiment of TLR2 and CD14, primary human HSCs were isolated by a two-step collagenase perfusion from surgical specimens of a normal human liver or a HCV-induced human cirrhotic liver as described previously. ${ }^{26}$ All tissues were obtained by qualified medical staff, with donor consent and the approval of the Columbia University Ethics Committee. HSC purity was assessed microscopically and by using the autofluorescence property of the stored retinoids in HSCs. Cell viability was determined using Trypan blue exclusion staining. HSC populations were more than $96 \%$ pure and viable. Isolated primary HSCs were seeded on uncoated plastic tissue culture dishes and cultured in DMEM (Life Technologies, Grand Island, NY) supplemented with 10\% heat inactivated FCS and standard antibiotics in 95\% air and $5 \% \mathrm{CO}_{2}$ humidified atmosphere at $37^{\circ} \mathrm{C}$. After 2 days in culture, HSCs from normal human liver had a quiescent phenotype, and after 14 days, the HSCs had an activated phenotype as described. ${ }^{29}$ The 
human monocytic cell line THP-1 (from American Type Culture Collection) was cultured in RPMI medium with $10 \%$ FCS. THP-1 cells were differentiated by treatment with $10 \mathrm{ng} / \mathrm{ml}$ of PMA for $18 \mathrm{~h}$.

\section{Western-Blot Analysis}

Whole-cell extracts were prepared from telomerasepositive human HSCs using Triton lysis buffer containing protease and phosphatase inhibitors, as described. ${ }^{29}$ Forty micrograms of protein were electrophoresed on 10\% SDS-polyacrylamide gels. The gels were then blotted onto a nitrocellulose membrane. Rabbit anti-human fibulin-2 (Santa Cruz Biotechnology, Santa Cruz, CA), rabbit anti-human type I collagen (Biodesign, Saco, ME), mouse antihuman $\alpha$ smooth muscle actin ( $\alpha$-SMA) (Dako, Glostrup, Denmark), rabbit anti-human TLR2 (eBioscience, San Diego, CA), rabbit anti-human CD14 (Santa Cruz Biotechnology), and mouse antihuman $\beta$-actin (Abcam, Cambridge, MA) antibodies, all diluted 1:1000, were used to detect immunoreactive fibulin-2, type I collagen, $\alpha$-SMA, TLR2, CD14, and $\beta$-actin, respectively, using an enhanced chemiluminescence light (ECL) detecting kit (Amersham Pharmacia Biotech, Piscataway, NJ) as previously described. ${ }^{29}$ JAR cell lysate (Santa Cruz Biotechnology) was used as a positive control for fibulin-2.

\section{Reverse Transcription-Polymerase Chain Reaction (RT-PCR) Analysis}

Total RNA was isolated from an activated human HSC cell line (hTERT), quiescent or in vitro cultureactivated primary human HSCs (from normal liver), in vivo-activated primary human HSCs (from HCVinduced cirrhotic liver), and differentiated THP-1 cells by the TRIzol method (Invitrogen, Carlsbad, CA) according to the manufacturer's instructions. One microgram of total RNA was reverse transcribed using $\mathrm{dT}_{15}$-oligonucleotide and Moloney murine leukemia virus reverse transcriptase (Perkin-Elmer/ Applied Biosystems, Foster City, CA) in a 25- $\mu$ l total reaction volume. One microliter of the reverse transcriptase reaction was subjected to PCR analysis to measure the mRNA levels of TLR2, CD14, and $\beta$ actin. PCR amplification was performed with Taq polymerase (Invitrogen, Carlsbad, CA) for 30 cycles at $95^{\circ} \mathrm{C}$ for $45 \mathrm{~s}, 54^{\circ} \mathrm{C}$ for $45 \mathrm{~s}$, and $72^{\circ} \mathrm{C}$ for $1 \mathrm{~min}$ for $\mathrm{TLR} 2$, and for 30 cycles at $92^{\circ} \mathrm{C}$ for $45 \mathrm{~s}, 56^{\circ} \mathrm{C}$ for $45 \mathrm{~s}$, and $72^{\circ} \mathrm{C}$ for $1 \mathrm{~min}$ for CD14 and $\beta$-actin. Primers for TLR2 were 5'-GCCAAAGTCTTGATTGA TTGG sense and 5'-TGGAAGTTCTCCAGCTCCTG antisense. PCR primers for CD14 were 5'-GGTGCC GCTGTGTAGGAAAGA sense and 5'-GGTCCTCGAG CGTCAGTTCCT antisense. PCR primers for $\beta$-actin were $5^{\prime}$-CCAACCGCGAGAAGATGACC sense and 5'-GATCTTCATGAGGTAGTCAGT antisense.
Table 1 Primer sequences for quantitative real-time PCR experiments

\begin{tabular}{ll}
\hline Primer & Sequence \\
\hline TLR2 & \\
Sense $\left(5^{\prime}-3^{\prime}\right)$ & TGG TAG TTG TGG GTT GAA GCA \\
Antisense $\left(5^{\prime}-3^{\prime}\right)$ & TAC CAT TGC GGT CAC AAG ACA \\
TaqMan probe $\left(5^{\prime}-3^{\prime}\right)$ & CTT GGA GAG GCT GAT GAT GAC CCC \\
& \\
CD14 & \\
Sense $\left(5^{\prime}-3^{\prime}\right)$ & GAC TTA TCG ACC ATG GAG CG \\
Antisense $\left(5^{\prime}-3^{\prime}\right)$ & GAA ATC TTC ATC GTC CAG CTC A \\
TaqMan probe $\left(5^{\prime}-3^{\prime}\right)$ & CAG AGA CGT GCA CCA GCG GCA GCA G \\
GAPDH & \\
Sense $\left(5^{\prime}-3^{\prime}\right)$ & GAA GGT GAA GGT CGG AGT C \\
Antisense $\left(5^{\prime}-3^{\prime}\right)$ & GAA GAT GGT GAT GGG ATT TC \\
TaqMan probe $\left(5^{\prime}-3^{\prime}\right)$ & CAA GCT TCC CGT TCT CAG CCT \\
\hline
\end{tabular}

\section{Quantitative Real-Time PCR}

The mRNA of TLR2 and CD14 were estimated by quantification of TLR2, CD14, and glyceraldehydes3-phosphate dehydrogenase (GAPDH) cDNA by the TaqMan real-time PCR method using a LightCycler (Roche, Mannheim, Germany). Primers for TLR2, CD14, and GAPDH were designed and synthesized by TIB MOLBIOL (Berlin, Germany) (Table 1). PCR conditions were as follows: pre-denaturation step for $10 \mathrm{~min}$ at $95^{\circ} \mathrm{C}$ followed by 45 cycles at $95^{\circ} \mathrm{C}$ and $54^{\circ} \mathrm{C}$ for $10 \mathrm{~s}$ each for TLR2, $95^{\circ} \mathrm{C}$ and $58^{\circ} \mathrm{C}$ for $10 \mathrm{~s}$ each for CD14, and $95^{\circ} \mathrm{C}$ and $49^{\circ} \mathrm{C}$ for $10 \mathrm{~s}$ each for GAPDH. The amplification protocol was followed by a cooling period of $40^{\circ} \mathrm{C}$ for $30 \mathrm{~s}$. The reaction mixture for the TaqMan probe assay contained $1 \mu \mathrm{l}$ of LightCycler FastStart Enzyme $(10 \times$ conc), $2 \mu \mathrm{l}$ of $10 \mathrm{pM}$ LightCycler FastStart Reaction Mix HybProbe, $2.4 \mu \mathrm{l}$ of $25 \mathrm{mM} \mathrm{MgCl}_{2}, 0.5 \mu \mathrm{l}$ of $5 \mu \mathrm{M}$ forward and reverse primers, $1 \mu \mathrm{l}$ cDNA, and $13.1 \mu \mathrm{l}$ water for a total volume of $20 \mu \mathrm{l}$. The fluorophore of the probe is 6-FAM in the $5^{\prime}$-position, which is quenched by TAMRA in the $3^{\prime}$-position when the probe is intact (Eurogentec, Seraing, Belgium). Fluorescence is generated after the probe is hybridized and digested by the $5^{\prime}$ exonuclease activity of Taq polymerase. All data were analyzed using Lightcycler software version 4.0. GAPDH was used for normalization of all experiments.

\section{Immunofluorescent Staining of TLR2}

Thirty thousand HSCs were plated onto an uncoated six-well plate and treated as described. After $24 \mathrm{~h}$ of TNF- $\alpha(10 \mathrm{ng} / \mathrm{ml})$ or IL- $1 \beta(5 \mathrm{ng} / \mathrm{ml})$ treatment, cells were fixed in ice-cold methanol for $10 \mathrm{~min}$, washed three times with PBS, and blocked with $10 \%$ normal goat serum in PBS. For the detection of human TLR2, cells were incubated with rabbit anti-human TLR2 (Santa Cruz Biotechnology, Santa Cruz, CA) primary antibody at 1:100 in blocking solution for $2 \mathrm{~h}$, and rhodamin-conjugated goat anti-rabbit 
secondary antibody (Pierce, Rockford, IL) at 1:100 for $1 \mathrm{~h}$. The cells were then visualized on an Olympus microscope (Olympus, Melville, NY) using a digital imaging system (Molecular Dynamics, Sunnyvale, CA).

\section{NF- $\kappa$ B Responsive Luciferase Assay}

Recombinant adenoviral vectors expressing a luciferase reporter gene driven by $\mathrm{NF}-\kappa \mathrm{B}$ transcriptional activation (Ad5NF- $\kappa$ BLuc), ${ }^{14}$ were used for the assessment of NF- $\kappa \mathrm{B}$ transcriptional activation. HSCs were infected with Ad5NF- $\kappa$ BLuc (multiplicity of infection 500) for $12 \mathrm{~h}$ in DMEM containing $0.5 \%$ FBS. After infection, the medium was exchanged with fresh medium containing $0.5 \%$ FBS, and the culture was continued for an additional $8 \mathrm{~h}$ before performing the individual experiments. A luciferase assay kit with luciferase cell culture lysis buffer (Promega, Madison, WI) was used to measure NF- $\kappa$ B-mediated transcriptional induction, according to the manufacturer's protocol. All measurements of luciferase activity (relative light units) were normalized to the protein concentration.

\section{Electrophoretic Mobility Shift Assay (EMSA)}

HSCs were stimulated with PGN (S. aureus) or LTA (B. subtilis) $(10 \mu \mathrm{g} / \mathrm{ml})$ for $1 \mathrm{~h}$ with or without pretreatment with TNF- $\alpha(10 \mathrm{ng} / \mathrm{ml})$ for $24 \mathrm{~h}$. Stimulation of cells with IL- $1 \beta(5 \mathrm{ng} / \mathrm{ml})$ for $15 \mathrm{~min}$ was used as a positive control. Nuclear extracts were prepared as previously described. ${ }^{30}$ Five micrograms of protein was incubated with a radiolabeled probe containing the NF- $\kappa \mathrm{B}$ consensus site (top: $5^{\prime}-$ AGTTGAGGGGACTTTCCCAGGC-3'; bottom: $5^{\prime}$ GCCTGGGAAAGTCCCCTCAACT-3'), separated by electrophoresis, and then analyzed by autoradiography as described previously. ${ }^{31}$ A 100 -fold molar excess of cold oligonucleotide was added as a competition experiment.

\section{IL-8 Enzyme-Linked Immunosorbent Assay}

After a 48-h serum starvation, HSCs were stimulated with PGN $(10 \mu \mathrm{g} / \mathrm{ml})$ or LTA $(10 \mu \mathrm{g} / \mathrm{ml})$ with or without TNF- $\alpha$ (10 ng/ml) for $24 \mathrm{~h}$. IL-8 secretion into the culture media by HSCs were measured by ELISA according to the manufacturer's instruction (R \& D Systems, Minneapolis, MN).

\section{Statistics}

Data were analyzed by the Student's $t$-test and twoway ANOVA using the Tukey method. Differences between sets of data were considered to be statistically significant when $P \leq 0.05$.

\section{Results}

\section{Telomerase-Positive Human HSCs and Primary Human HSCs Express TLR2 and CD14}

The expression of activated HSC markers including type I collagen and $\alpha$-SMA, and a marker of myofibroblast fibulin-2 in the telomerase-positive human HSC cell line (hTERT) was first assessed by Western blotting. Telomerase-positive human HSCs expressed type I collagen and $\alpha$-SMA but not fibulin2, suggesting that telomerase-positive human HSCs correspond to activated human HSCs (Figure 1a). The expression of PGN or LTA receptor molecules, including TLR2 and CD14, in human HSCs was assessed by RT-PCR. In telomerase-positive human HSCs (hTERT), mRNA encoding TLR2 and CD14 was clearly detected. THP-1 cells, a human monocyte cell line, served as a positive control (Figure 1b, left panel). We also checked the mRNA expression of TLR2 and CD14 in primary human HSCs. In quiescent HSCs, TLR2 mRNA was weakly detected; however, CD14 mRNA was not detected. The mRNAs for TLR2 and CD14 were clearly detected in both in vitro culture-activated HSCs (from normal

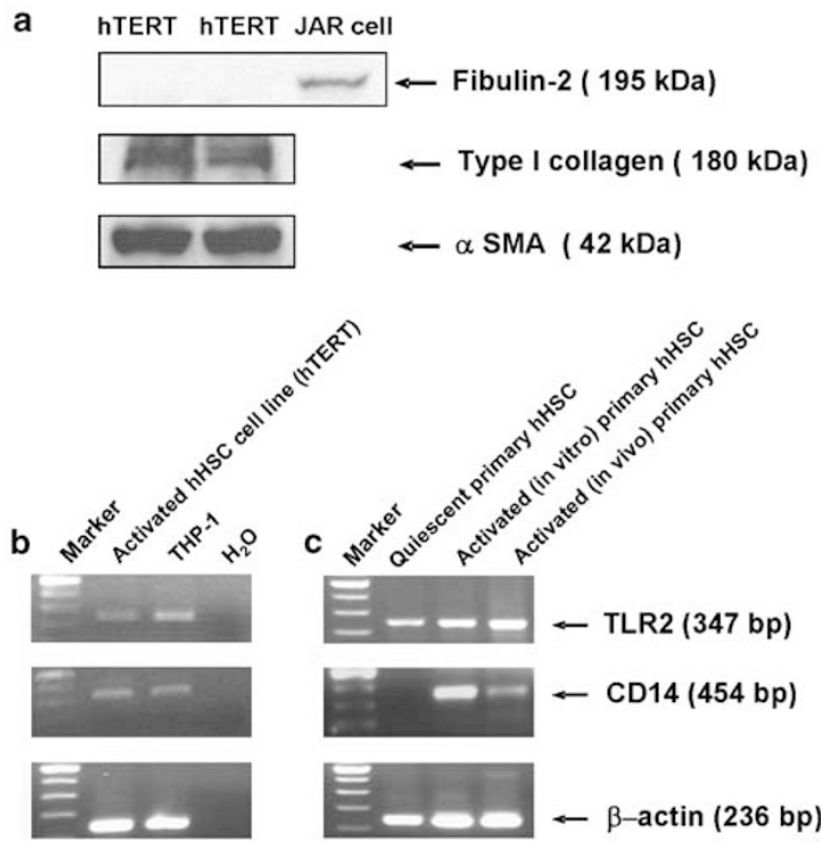

Figure 1 Characterization of telomerase-positive HSCs and expression of peptidoglycan and lipoteichoic acid receptors in primary human HSCs. (a) The expression of type I collagen, $\alpha$-SMA, and fibulin-2 in a telomerase-positive human HSC cell line (hTERT) was assessed by Western blotting. JAR cell lysate was used as a positive control for fibulin-2. (b, c) TLR2 and CD14 mRNA expression was assessed by RT-PCR in telomerase-positive HSC cell line and primary human HSCs. (b) Total RNA was obtained from an activated human HSC cell line (hTERT) or from differentiated THP-1 cells. THP-1 cells were differentiated by treatment with $10 \mathrm{ng} / \mathrm{ml}$ of PMA for $18 \mathrm{~h}$, and were used as a positive control. (c) Total RNA was obtained from quiescent human HSCs or in vitro culture-activated human HSCs (from normal liver), and in vivo activated human HSCs (from HCVinduced cirrhotic liver). 
liver) and in vivo activated HSCs (from HCVinduced cirrhotic liver) (Figure 1b, right panel).

\section{Separately, TNF- $\alpha$ and IL-1 $\beta$ Upregulate the Expression of TLR2 in HSCs}

We performed quantitative real-time PCR to quantitate the change of TLR2 and CD14 mRNA expression during TNF- $\alpha$, IL- $1 \beta$, LPS, and PGN stimulation. Real-time PCR showed that TNF- $\alpha$ strikingly increased TLR2 mRNA expression 149-fold at $12 \mathrm{~h}$, and 572 -fold $24 \mathrm{~h}$ after stimulation compared to baseline levels (Figure 2a); on the other hand, TNF- $\alpha$ only weakly upregulated CD14 expression, by 3.7fold, at $24 \mathrm{~h}$ (Figure 2b). IL-1 $\beta$ upregulated TLR2 mRNA expression to a 14.1-fold maximum at $12 \mathrm{~h}$
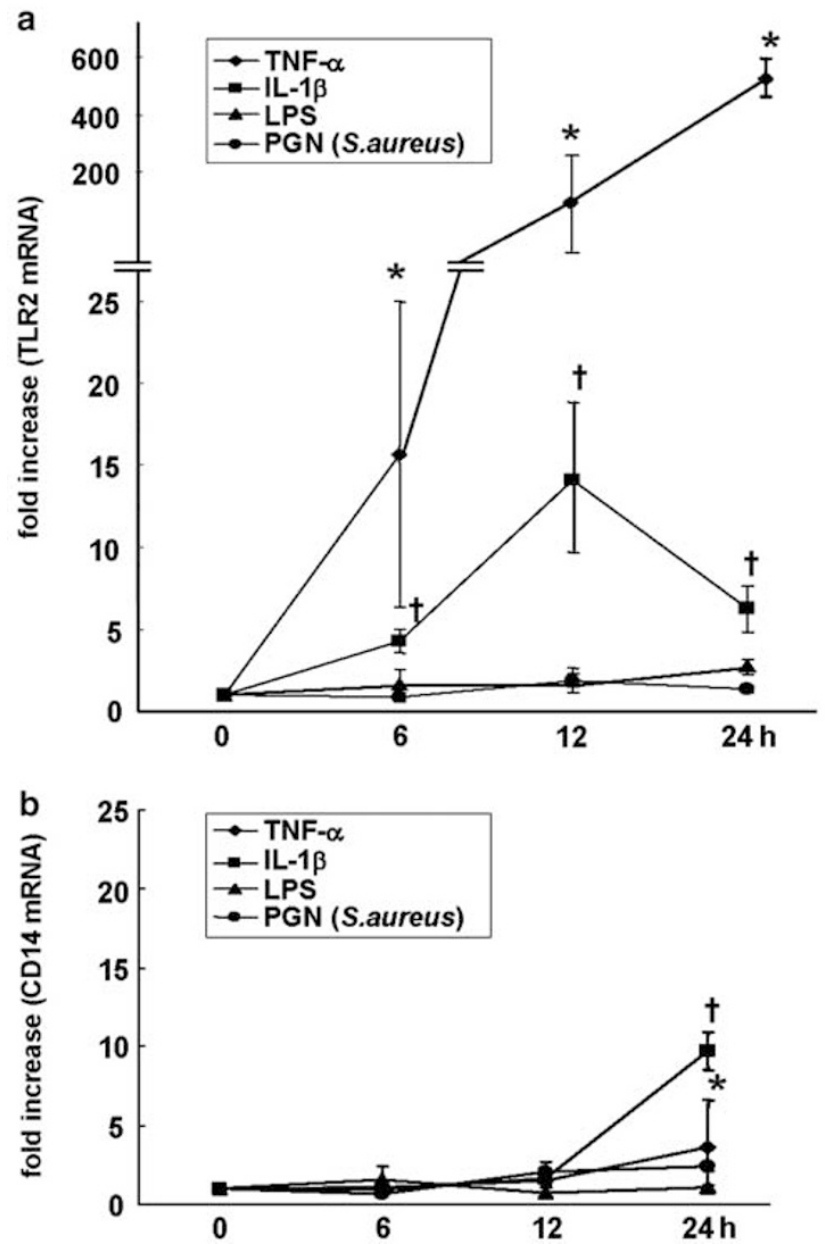

Figure 2 TLR2 and CD14 mRNA expression after stimulation with TNF- $\alpha$ or IL- $1 \beta$ for different periods of time in HSCs. Quantitation of TLR2 (a) or CD14 mRNA (b) expression for different periods of time after TNF- $\alpha(10 \mathrm{ng} / \mathrm{ml}), \mathrm{IL}-1 \beta(5 \mathrm{ng} / \mathrm{ml})$, LPS $(1 \mu \mathrm{g} / \mathrm{ml})$, or PGN stimulation from $S$. aureus $(10 \mu \mathrm{g} / \mathrm{ml})$ under serum-free conditions in activated HSCs was done by quantitative real-time RT-PCR. Data represent the mean \pm s.d. of three independent experiments performed in duplicate, and are expressed as fold-increase over cells at time point zero. *: $P<0.01$, when compared with HSCs stimulated with TNF- $\alpha$ at time point zero, $\dagger: P<0.01$, when compared with HSCs stimulated with IL- $1 \beta$ at time point zero. followed by a decrease in mRNA expression at $24 \mathrm{~h}$ after stimulation (Figure 2a), and IL-1 $\beta$ upregulated CD14 expression to a 9.8-fold maximum after $24 \mathrm{~h}$ of stimulation (Figure 2b). LPS and PGN from $S$. aureus did not significantly upregulate TLR2 and CD14 mRNA expression in HSCs.

We looked at changes of TLR2 and CD14 expression in response to TNF- $\alpha$ or IL- $1 \beta$ in HSCs by Western blotting (Figure 3a). The TLR2 protein level was upregulated at 24 and $48 \mathrm{~h}$ after stimulation with TNF $\alpha$ or IL- $1 \beta$ in HSCs. However, the expression of CD14 protein was not significantly changed after TNF- $\alpha$ or IL- $1 \beta$ treatment. Immunofluorescent staining was performed to investigate the change of TLR2 protein expression after cytokine stimulation. Activated human HSCs expressed TLR2 protein mainly in the cytoplasm (Figure 3c). After $24 \mathrm{~h}$ of TNF- $\alpha(10 \mathrm{ng} / \mathrm{ml})$ or IL- $1 \beta(5 \mathrm{ng} / \mathrm{ml})$ stimulation, TLR2 expression was markedly upregulated (Figure 3d,e). These results demonstrated that TLR2, a major receptor component of gram-positive bacterial products such as peptidoglycan and lipoteichoic acid, was significantly upregulated by TNF- $\alpha$ and IL-1 $\beta$.

\section{Peptidoglycan and Lipoteichoic Acid Activate $\mathrm{NF}-\boldsymbol{\kappa} \mathrm{B}$ in HSCs}

To investigate whether PGN and LTA induce NF- $\kappa \mathrm{B}$ activation, we performed a NF- $\kappa \mathrm{B}$-driven luciferase reporter assay. PGN from $S$. aureus, PGN from $B$. subtilis and LTA from $S$. pyogenes induced NF- $\kappa$ B transcriptional activity 1.8-fold, 2.9-fold and 2.8fold compared to an untreated control, respectively $(P<0.01)$ (Figure 4). Polymyxin B, a LPS inhibitor, did not inhibit PGN- or LTA-induced NF- $\kappa$ B activation in HSCs. In addition, LPS did not activate NF$\kappa \mathrm{B}$ in serum-free conditions, demonstrating that the PGN- or LTA-induced NF- $\kappa$ B activation was not mediated by contaminating LPS.

\section{TNF- $\alpha$ and IL-1 $\beta$ Enhance Peptidoglycan- and Lipoteichoic Acid-Induced NF- $\kappa$ B Activation in HSCs}

We examined whether priming with inflammatory cytokines, such as TNF- $\alpha$ or IL- $1 \beta$, modulates NF- $\kappa$ B transcriptional activation in activated human HSCs. HSCs were treated with TNF- $\alpha(10 \mathrm{ng} / \mathrm{ml})$ or IL- $1 \beta$ $(5 \mathrm{ng} / \mathrm{ml})$ for $24 \mathrm{~h}$, and then stimulated with PGN or LTA for $8 \mathrm{~h}$. As shown in Figure 5a, TNF- $\alpha$ or IL- $1 \beta$ primed HSCs showed significantly greater NF- $\kappa \mathrm{B}$ transcriptional activation than nonprimed HSCs in response to PGN or LTA. Next, we examined NF- $\kappa$ B nuclear binding activity using EMSA. Separately, PGN and LTA weakly induced NF- $\kappa$ B nuclear binding, and interestingly, preincubation of HSCs with TNF- $\alpha$ for $24 \mathrm{~h}$ significantly upregulated PGNand LTA-induced NF- $\kappa$ B binding activity (Figure 5b). These results suggest that cytokines such as 
a

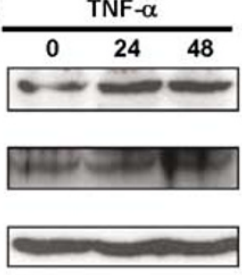

IL-1ß

$\begin{array}{lll}0 & 24 & 48 \mathrm{~h}\end{array}$

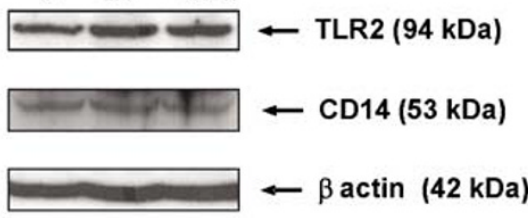

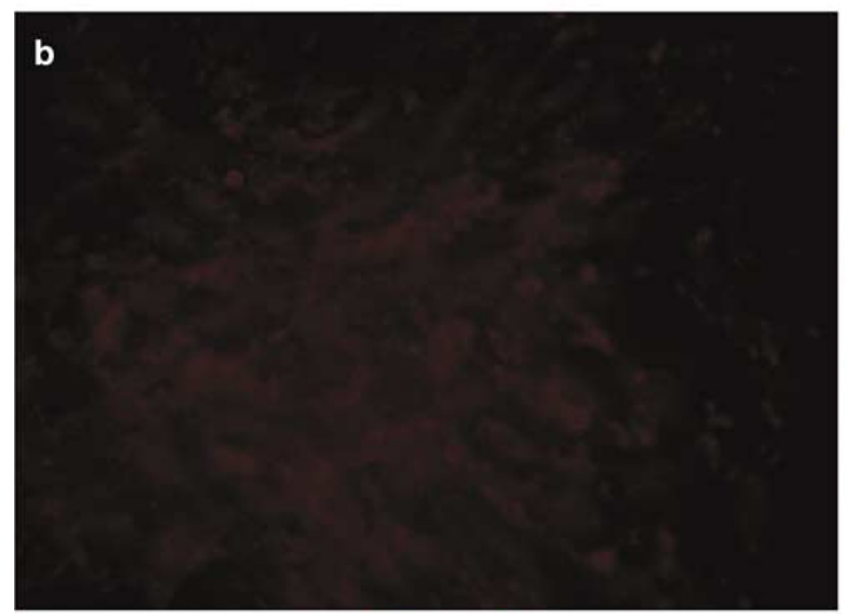
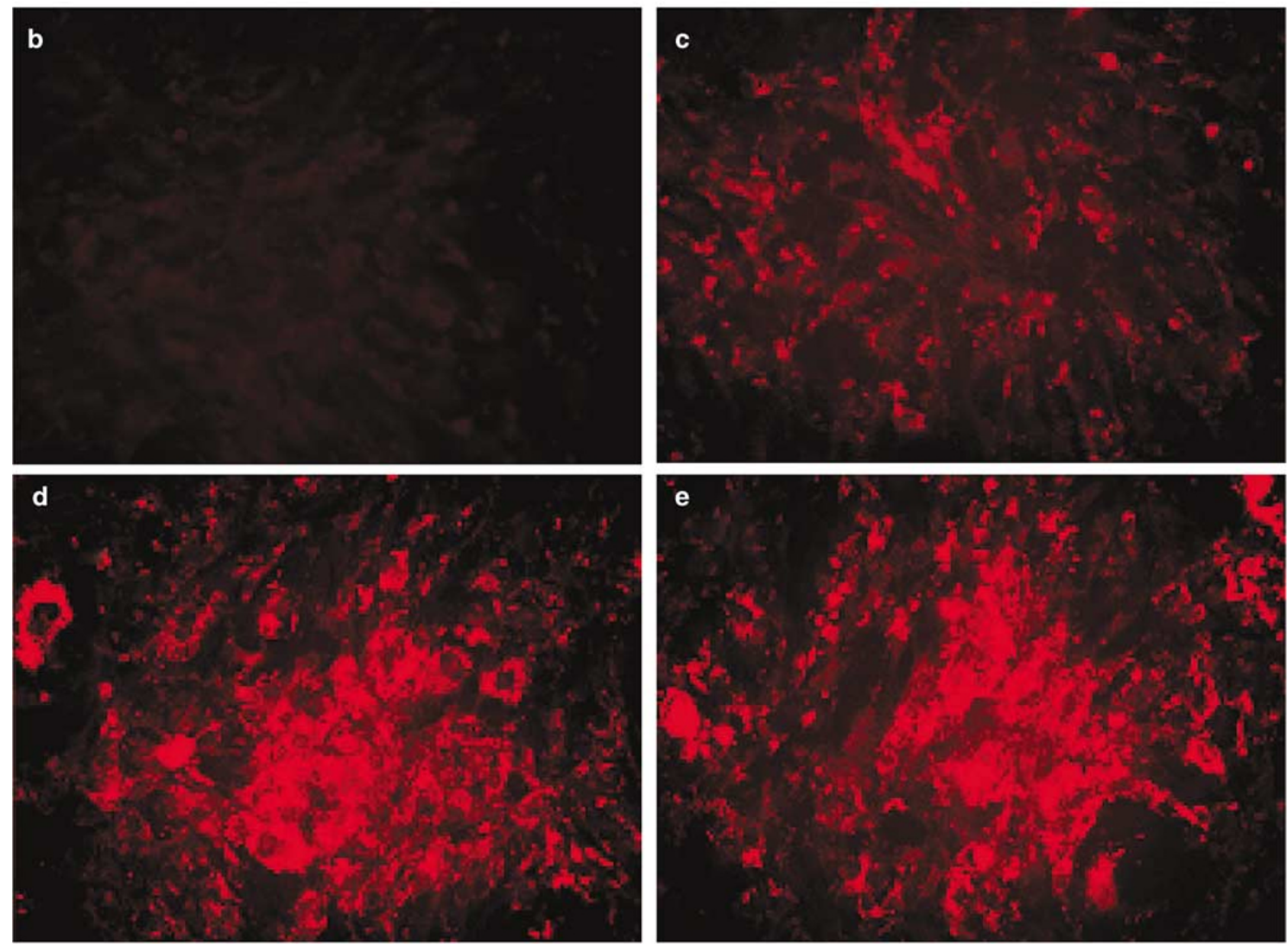

Figure 3 Upregulation of TLR2 protein expression in activated human HSCs in response to TNF- $\alpha$ or IL-1 $\beta$. (a) Quantitation of TLR 2 and CD14 protein expression for different periods of time after TNF- $\alpha(10 \mathrm{ng} / \mathrm{ml})$ or IL- $1 \beta(5 \mathrm{ng} / \mathrm{ml})$ stimulation in activated HSCs was done by Western blotting. (b-e) Immunofluorescent staining was used to assess TLR2 protein expression in activated human HSCs. Cells were cultured in DMEM without serum. Cells were treated for $24 \mathrm{~h}$ as follows: (b, c) serum-free DMEM, (d) TNF- $\alpha(10 \mathrm{ng} / \mathrm{ml})$, and (e) IL- $1 \beta$ $(5 \mathrm{ng} / \mathrm{ml})$. After $24 \mathrm{~h}$ of stimulation, (b) cells were fixed and stained with secondary antibody only, or (c-e) cells were stained with rabbit anti-human TLR2 primary antibody and goat anti-rabbit rhodamin-conjugated secondary antibody.

TNF- $\alpha$ and IL-1 $\beta$ enhance PGN- and LTA-induced $\mathrm{NF}-\kappa \mathrm{B}$ activation in activated human HSCs.

\section{TLR2 Blocking Antibody Inhibits NF- $\kappa$ B Activation and IL-8 Production by TNF- $\alpha$-Primed and Nonprimed HSCs in Response to Peptidoglycan or Lipoteichoic Acid}

We examined whether TNF- $\alpha$-primed or nonprimed HSCs activate NF- $\kappa \mathrm{B}$ and produce IL-8 through TLR2. A NF- $\kappa$ B driven reporter assay showed that peptidoglycan- and lipoteichoic acid-induced NF$\kappa \mathrm{B}$ activation was almost completely suppressed to a baseline level by preincubation with TLR2 blocking $\mathrm{Ab}$ (T2.5), but not with isotype $\operatorname{IgG}_{1} \mathrm{Ab}$, both in nonprimed and TNF- $\alpha$-primed HSCs (Figure 6a,b). As shown by ELISA (Figure 7a-c), the peptidoglycan- and lipoteichoic acid-induced IL-8 secretion in HSCs was completely inhibited by preincubation with TLR2 blocking Ab (T2.5), but not with isotype $\mathrm{IgG}_{1} \mathrm{Ab}$. After priming HSCs by pretreatment with TNF- $\alpha$ for $24 \mathrm{~h}$, peptidoglycan- and lipoteichoic acid-induced IL-8 secretion was further enhanced, 
but IL-8 secretion was completely inhibited by preincubation with TLR2 blocking Ab (T2.5) (Figure $7 \mathrm{a}-\mathrm{c})$. These results demonstrated that PGN and LTA have a direct proinflammatory action through TLR2 in activated human HSCs.

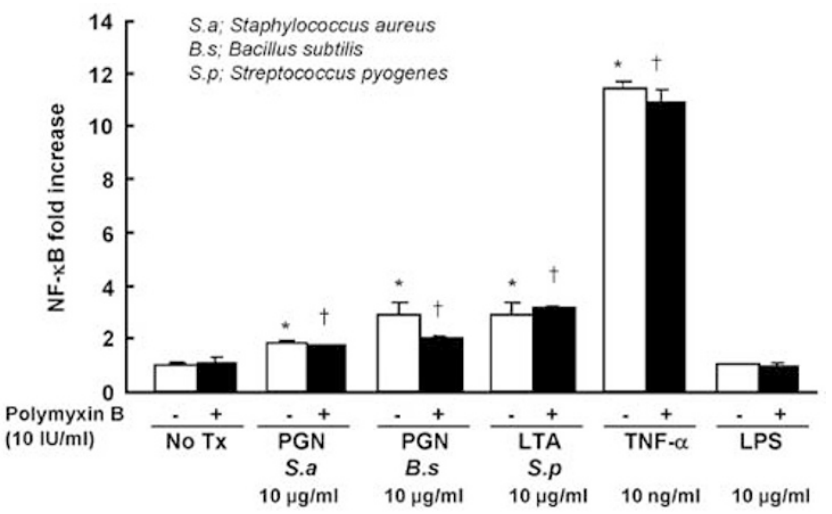

Figure 4 Peptidoglycan or lipoteichoic acid induces NF- $\kappa \mathrm{B}$ transcriptional activation in activated human HSCs. NF- $\kappa \mathrm{B}$ transcriptional activation was assessed with NF- $\kappa \mathrm{B}$-driven luciferase assay. Activated human HSCs were infected with Ad5NF$\kappa$ BLuc (MOI 500) for $12 \mathrm{~h}$ in DMEM containing $0.5 \%$ FCS. At $20 \mathrm{~h}$ post-infection, HSCs were stimulated with PGN ( $S$. aureus) $(10 \mu \mathrm{g} / \mathrm{ml})$, PGN (B. subtilis) $(10 \mu \mathrm{g} / \mathrm{ml})$, LTA (S. pyogenes) $(10 \mu \mathrm{g} / \mathrm{ml})$, TNF- $\alpha(10 \mathrm{ng} / \mathrm{ml})$, or LPS $(1 \mu \mathrm{g} / \mathrm{ml})$ for $8 \mathrm{~h}$ in serumfree conditions with or without pretreatment of Polymyxin B $(10 \mathrm{IU} / \mathrm{ml})$ for $30 \mathrm{~min}$. Cells were lysed, and NF- $\kappa \mathrm{B}$-mediated luciferase activity was quantified. Data represent the mean + s.d. of three independent experiments performed in duplicate, and are expressed as fold-increase over unstimulated cells. All measurements of luciferase activity were normalized to the protein concentration. ${ }^{*}, \dagger: P<0.01$, when compared with unstimulated HSCs.

Figure 5 Enhanced NF- $\kappa$ B activation in TNF- $\alpha$ - or IL- $1 \beta$-primed HSCs after stimulation with peptidoglycan or lipoteichoic acid. (a) Activated human HSCs were infected with Ad5NF- $\kappa$ BLuc (MOI 500) for $12 \mathrm{~h}$ in DMEM containing 0.5\% FCS. HSCs were then incubated in serum-free DMEM with TNF- $\alpha(10 \mathrm{ng} / \mathrm{ml})$ or IL$1 \beta(10 \mathrm{ng} / \mathrm{ml})$ for $24 \mathrm{~h}$. After washing three times, HSCs were stimulated with media, PGN (S. aureus) $(10 \mu \mathrm{g} / \mathrm{ml})$, PGN $(B$. subtilis $)(10 \mu \mathrm{g} / \mathrm{ml})$, or LTA $(S$. pyogenes $)(10 \mu \mathrm{g} / \mathrm{ml})$ for $8 \mathrm{~h}$ in serum-free conditions. Data represent the mean \pm s.d. of three independent experiments performed in duplicate, and are expressed as fold-increase over unstimulated cells. All measurements of luciferase activity were normalized to the protein concentration. ${ }^{*}, \dagger, \ddagger: P<0.01$, when compared to control HSCs without stimulation; $\S: P<0.01$, unprimed HSCs vs TNF- $\alpha$-primed HSCs; ${ }^{* *}: P<0.01$, unprimed HSCs vs IL-1 $\beta$-primed HSCs; \#: $P<0.01$, TNF- $\alpha$-primed HSCs vs IL-1 $\beta$-primed HSCs. (b) Activated human HSCs were incubated with DMEM alone (lanes 1-3) or with TNF- $\alpha(10 \mathrm{ng} / \mathrm{ml})$ for $24 \mathrm{~h}$ (lanes $4-8)$. Cells were then treated as follows: lanes 1,4, DMEM; lanes 2,5, PGN from $S$. aureus $(10 \mu \mathrm{g} / \mathrm{ml})$; lanes 3,6. LTA from $S$. pyogenes $(10 \mu \mathrm{g} / \mathrm{ml})$; and lane 7 , $\mathrm{IL}-1 \beta(5 \mathrm{ng} / \mathrm{ml})$. Lanes 8 is the same as lane 5 with the addition of a 100-fold molar excess of cold oligonucleotide as a competitor. Nuclear extracts ( $5 \mu \mathrm{g}$ ) were assayed for NF- $\kappa$ B binding activity by EMSA using a radiolabeled consensus NF- $\kappa$ B site as a probe. A representation of three independent experiments is shown. * $\dagger$ : $P<0.01$, when compared to control HSCs without stimulation; $\ddagger$ : $P<0.01$, unprimed HSCs vs TNF- $\alpha$-primed HSCs.

\section{Discussion}

Chronic hepatic inflammation results in fibrosis of the liver. Cytokines, chemokines, and growth factors, such as TNF- $\alpha$, IL-1 $\beta$, IL-6, interferon- $\gamma$, IL-8, macrophage inflammatory protein-1, macrophage chemoattractant factor-1, and transforming growth factor- $\beta$, are all upregulated upon chronic hepatic inflammation, and these mediators cause HSC activation that results in liver fibrosis. ${ }^{32}$ Based on the importance of chronic inflammation in the development of hepatic fibrosis, anti-inflammatory therapy is a potential therapeutic modality for the prevention or reversal of hepatic fibrosis. Hepatic stellate cells are a critical cell type for the development of hepatic fibrosis. In this study we used telomerase-positive human HSCs because they

a
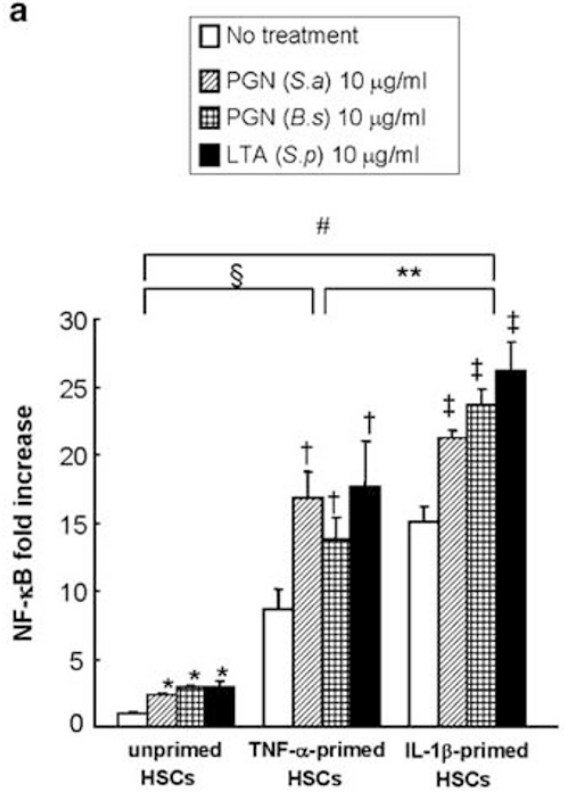

b
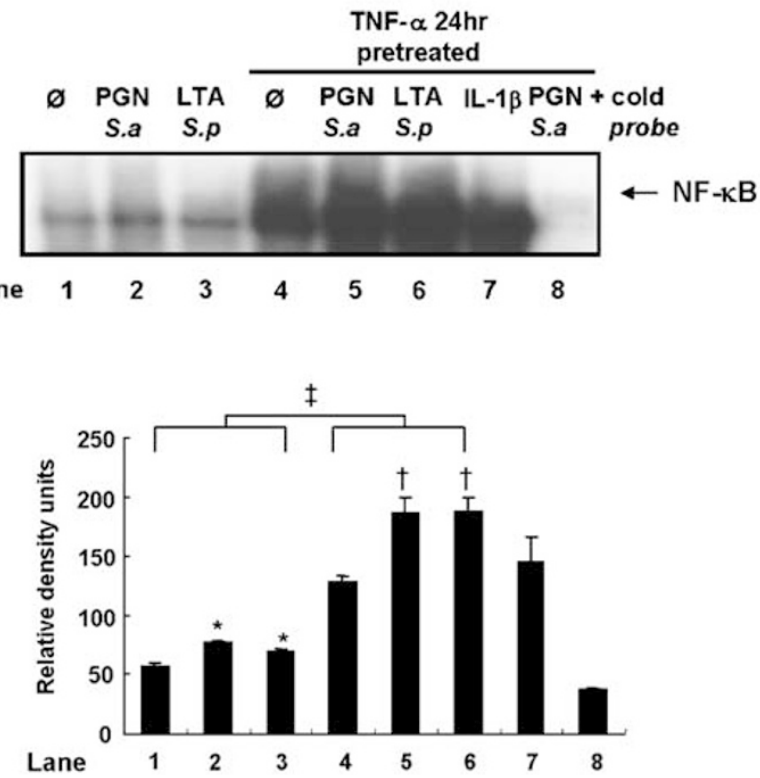
proved to have morphological and functional characteristics of activated HSCs. Telomerase positive human HSCs expressed Type I collagen and $\alpha$ smooth muscle actin but not fibulin 2, suggesting

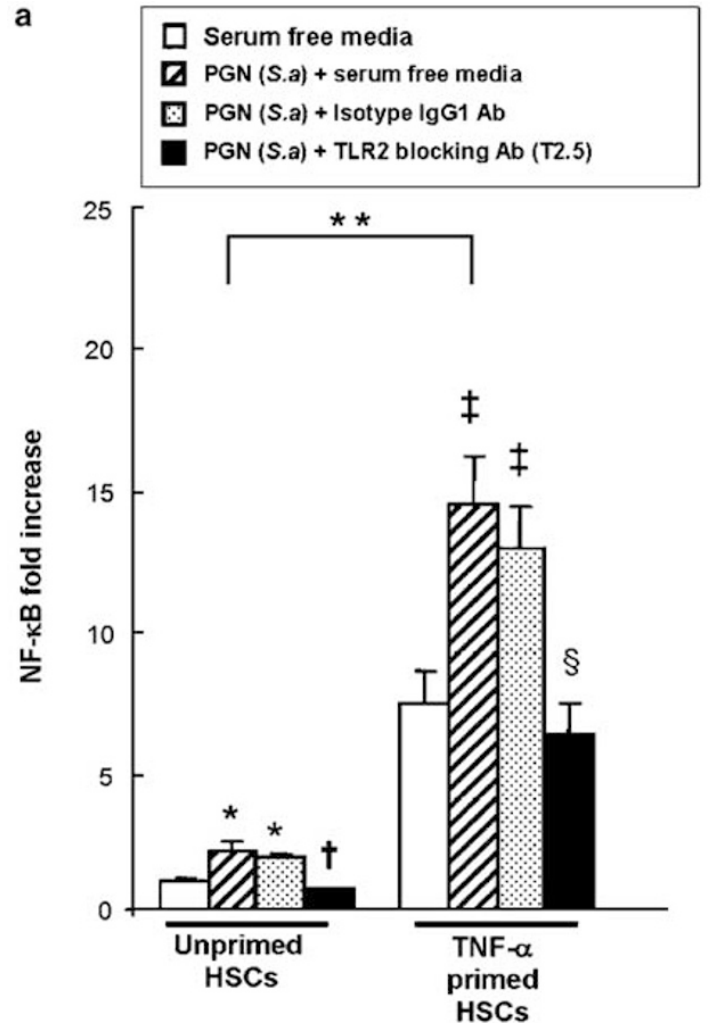

b
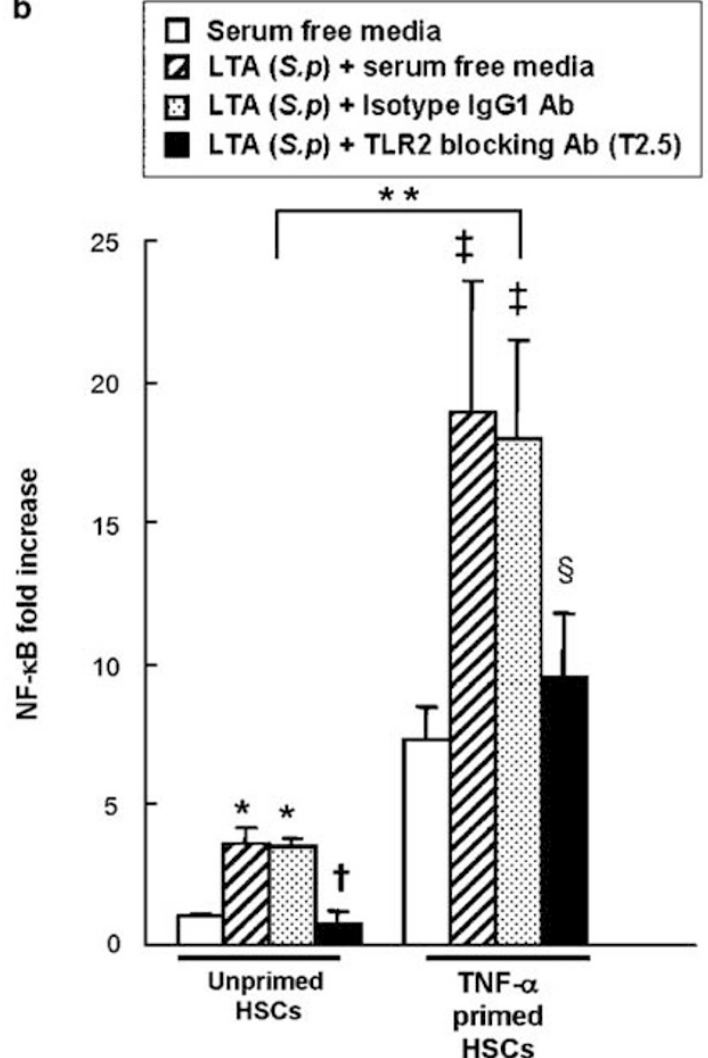

that telomerase-positive HSCs correspond to activated HSCs but not to myofibroblasts. ${ }^{33}$

TLRs, a family of phylogenetically conserved receptors, have attracted particular interest because of their functions in the regulation and linking of innate immune and inflammatory processes. We previously demonstrated that TLR4, a receptor for lipopolysaccharide (LPS), was expressed in human HSCs and demonstrated that LPS has a direct proinflammatory action on HSCs via TLR4-mediated signaling. These findings suggest that bacterial product-induced inflammatory signaling in HSCs may be important, and could be a therapeutic target for hepatic inflammation and subsequent fibrosis.

Increased portal bacteremia, including gram-positive and gram-negative bacteria, occurs in patients with chronic liver diseases. Hence, this study examined the effect of gram-positive bacterial products on HSCs. Peptidoglycan and lipoteichoic acid are major proteins on the cell wall of grampositive bacteria. TLR2 is a receptor for several ligands such as lipoprotein, peptidoglycan, lipoteichoic acid, lipoarabinomannan, atypical liposaccharide, and heat-shock protein $70 .^{7-9}$ CD14 was shown to be a co-receptor for TLR4 and TLR2. CD14 contains discrete binding sites that are different for LPS and PGN. ${ }^{34,35}$ It has been reported that grampositive PGN and LTA trigger cytokine release from innate immune cells. ${ }^{36,37}$ In this study, we investigated the role of gram-positive bacterial products in the inflammation of hepatic stellate cells. Our study demonstrated that both telomerase-positive human HSCs (hTERT) and primary human HSCs express TLR2 and CD14, which are receptors for PGN and LTA signaling. The findings that TLR2 and CD14 are upregulated in both in vitro and in vivo activated HSCs compared to quiescent HSCs suggest that innate inflammatory actions in response to gram positive bacterial products are coordinantly upregulated in activated HSCs. Our study showed that peptidoglycan and lipoteichoic acid from different strains of gram-positive bacteria weakly induced

Figure 6 Peptidoglycan- or lipoteichoic acid-induced NF- $\kappa \mathrm{B}$ activation is inhibited by TLR2 blocking antibody in TNF- $\alpha$ primed and nonprimed HSCs. Activated human HSCs were infected with Ad5NF- $\kappa$ BLuc (MOI 500) for $12 \mathrm{~h}$ in DMEM containing $0.5 \%$ FCS. HSCs were then incubated with serumfree DMEM or TNF- $\alpha(10 \mathrm{ng} / \mathrm{ml})$ for $24 \mathrm{~h}$. After washing three times, HSCs were stimulated with: (a) serum-free media, PGN from $S$. aureus $(10 \mu \mathrm{g} / \mathrm{ml})$ via preincubation with media, antiTLR2 bloking $\mathrm{Ab}(20 \mu \mathrm{g} / \mathrm{ml})$, or $\mathrm{IgG}_{1} \mathrm{Ab}$ for $30 \mathrm{~min}$; or (b) serumfree media, LTA from $S$. pyogenes $(10 \mu \mathrm{g} / \mathrm{ml})$ via preincubation with media, anti-TLR2 bloking $\mathrm{Ab}(20 \mu \mathrm{g} / \mathrm{ml})$, or $\mathrm{IgG}_{1} \mathrm{Ab}$ for $30 \mathrm{~min}$. Cells were lysed, and NF- $\kappa \mathrm{B}$-mediated luciferase activity was quantified. Data represent the mean \pm s.d. of three independent experiments performed in duplicate and are expressed as fold-increase over unstimulated cells. All measurements of luciferase activity were normalized to the protein concentration. ${ }^{*}, t: P<0.01$, when compared to control HSCs without stimulation; $\dagger, \S: P<0.01$, compared to HSCs with stimulation after preincubation with $\mathrm{IgG}_{1} \mathrm{Ab} ;^{* *}: P<0.01$, unprimed HSCs vs TNF$\alpha$-primed HSCs. 
a

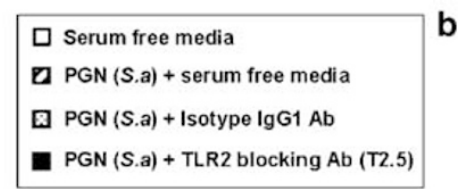

b
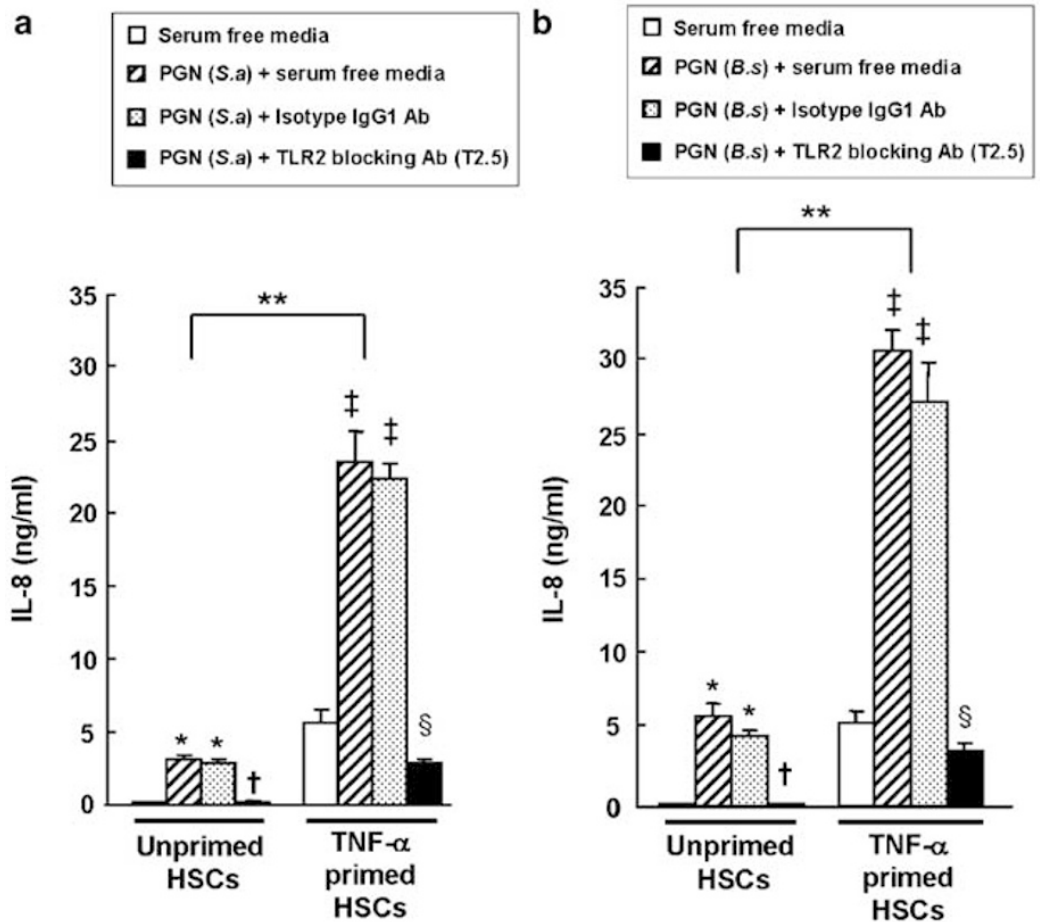

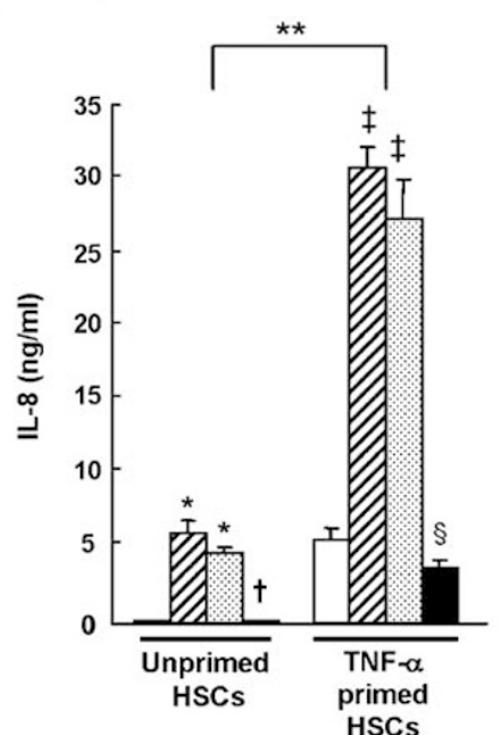

C

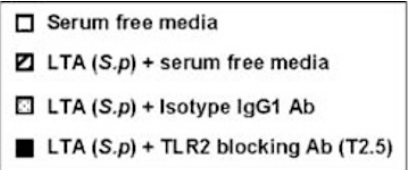

$\square$ Serum free media

LTA (S.p) + TLR2 blocking Ab (T2.5)

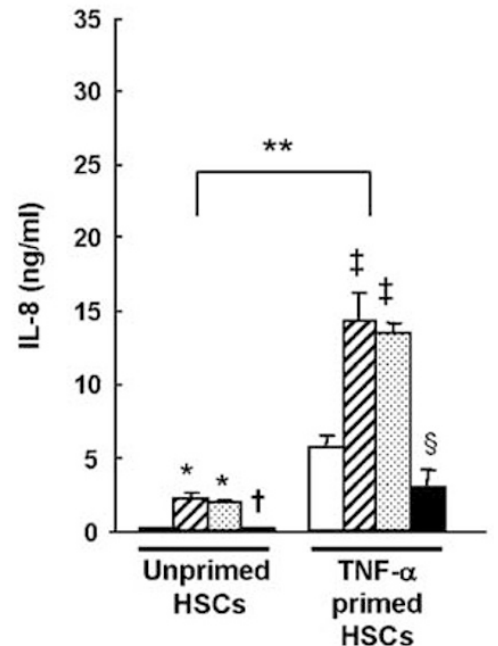

Figure 7 Peptidoglycan- or lipoteichoic acid-induced IL-8 production is inhibited by TLR2 blocking antibody in TNF- $\alpha$-primed and nonprimed HSCs. HSCs were incubated in serum-free DMEM or TNF- $\alpha(10 \mathrm{ng} / \mathrm{ml})$ for $24 \mathrm{~h}$. After washing three times, HSC were stimulated with: (a) serum-free media, PGN from $S$. aureus $(10 \mu \mathrm{g} / \mathrm{ml})$ via preincubation with media, anti-TLR2 bloking Ab $(20 \mu \mathrm{g} / \mathrm{ml})$, or $\mathrm{IgG}_{1} \mathrm{Ab}$ for $30 \mathrm{~min}$; (b) serum-free media, PGN from B. subtilis $(10 \mu \mathrm{g} / \mathrm{ml})$ via preincubation with media, anti-TLR2 blocking Ab (20 $\mu \mathrm{g} /$ $\mathrm{ml}$ ), or IgG 1 Ab for $30 \mathrm{~min}$; (c) serum-free media, LTA from $S$. pyogenes $(10 \mu \mathrm{g} / \mathrm{ml})$ via preincubation with media, anti-TLR2 blocking Ab $(20 \mu \mathrm{g} / \mathrm{ml})$, or $\mathrm{IgG}_{1} \mathrm{Ab}$ for $30 \mathrm{~min}$. Secreted IL-8 was quantified by ELISA from HSC culture supernatant. Data represent the mean \pm s.d. of two independent experiments performed in triplicate. *, $\ddagger: P<0.01$, when compared to control HSCs without stimulation; $\dagger, \S: P<0.01$, compared to HSCs with stimulation after preincubation with $\operatorname{IgG}_{1} \mathrm{Ab} ; .^{*}: P<0.01$, unprimed HSCs vs TNF- $\alpha$-primed HSCs.

$\mathrm{NF}-\kappa \mathrm{B}$ in human HSCs, which is a major proinflammatory signaling mediator. In addition, PGN and LTA significantly induced proinflammatory IL-8 secretion in activated human HSCs. The minimal active concentration of PGN or LTA for proinflammatory response in HSCs was $1 \mu \mathrm{g} / \mathrm{ml}$, which was 100 times higher than that of LPS (as low as $1 \mathrm{ng}$ / $\mathrm{ml}$ ). These findings were comparable to previous studies using monocytes. ${ }^{9,35}$

It is noteworthy that the priming of HSCs with TNF- $\alpha$ or IL- $1 \beta$ significantly upregulated the expression of TLR2 mRNA and protein in human HSCs. There was some discrepancy of time course between TLR2 mRNA expression and protein expression in IL-1 $\beta$-stimulated HSCs. We think that the discrepancy may be caused by a different signaling pathway of IL- $1 \beta$ compared to $\mathrm{TNF} \alpha$, and posttranscriptional or post-translational modification of TLR2 mRNA in IL- $1 \beta$-stimulated HSCs. PGN- or LTA-induced NF- $\kappa$ B activation and IL-8 secretion was further enhanced by pretreatment of HSCs with TNF- $\alpha$ or IL- $1 \beta$. In chronic hepatic inflammation, various proinflammatory cytokines are upregulated. Induction and upregulation of TLR2 by inflammatory cytokines, such as TNF- $\alpha$ and IL- $1 \beta$, in HSCs may have important clinical implications for hepatic inflammation and fibrosis in liver cirrhosis patients due to its rendering HSCs more sensitive to microbial ligands in portal circulation that specifically use TLR2.

Preincubation of HSCs with TLR2 blocking antibody completely inhibited PGN- or LTA-induced $\mathrm{NF}-\kappa \mathrm{B}$ activation and IL-8 secretion in TNF- $\alpha-$ primed and unprimed HSCs. These results suggest that TLR2 is critical in PGN- or LTA-induced inflammatory action in HSCs, and the upregulation of critical components of PGN or LTA signaling is, at least in part, a mechanism of response enhancement by TNF- $\alpha$ or IL- $1 \beta$. It was reported that priming or concomitant exposure of mononuclear phagocytes to IFN- $\gamma$ dramatically increased their responsiveness to LPS, ${ }^{19}$ and the molecular basis for the priming and synergism of IFN- $\gamma$ was shown as the upregulation of TLR4 and MD2 mRNA and surface expression on mononuclear phagocytes. ${ }^{23}$ In human endothelial cells, LPS and TNF- $\alpha$ separately induce TLR2 upregulation through TLR4-, MyD88-, and NF$\kappa \mathrm{B}$-dependent signaling. ${ }^{38}$ Additional mechanisms besides the upregulation of TLR2 may play a role in enhancing the response of TNF- $\alpha$ and IL- $1 \beta$ in HSCs to PGN/LTA. Recently, receptor synergism between several members of the TLR family and the adenosine $A_{2 a}$ receptor has been reported. ${ }^{39}$ Further research is needed to investigate whether synergy 
exists between TLRs and receptors for TNF- $\alpha$ and IL-1 $\beta$ signaling in HSCs.

Our study demonstrates that human HSCs are equipped with receptors for gram-positive bacterial products such as PGN and LTA, including TLR2 and CD14, which activate NF- $\kappa \mathrm{B}$ and produce proinflammatory IL-8 in response to PGN and LTA. In addition, we showed an upregulation of TLR2 by priming HSCs with inflammatory cytokines, such as TNF- $\alpha$ and IL- $1 \beta$, and the subsequent enhancement of NF- $\kappa$ B activation and IL-8 production in response to PGN and LTA treatment. These results suggest that TLR2 signaling may be an important therapeutic target for hepatic inflammation and fibrosis, especially in patients with ongoing chronic hepatic inflammation.

\section{Acknowledgement}

This work was supported by the Korea Research Foundation Grant KRF-2004-003-E00078.

\section{Duality of interest}

None declared.

\section{References}

1 Friedman SL. Molecular regulation of hepatic fibrosis, an integrated cellular response to tissue injury. J Biol Chem 2000;275:2247-2250.

2 Vinas O, Bataller R, Sancho-Bru P, et al. Human hepatic stellate cells show features of antigen-presenting cells and stimulate lymphocyte proliferation. Hepatology 2003;38:919-929.

3 Akira S, Takeda K. Toll-like receptor signalling. Nat Rev Immunol 2004;4:499-511.

4 Beutler B, Hoebe K, Shamel L. Forward genetic dissection of afferent immunity: the role of TIR adapter proteins in innate and adaptive immune responses. $\mathrm{C}$ R Biol 2004;327:571-580.

5 Slack JL, Schooley K, Bonnert TP, et al. Identification of two major sites in the type I interleukin-1 receptor cytoplasmic region responsible for coupling to proinflammatory signaling pathways. J Biol Chem 2000; 275:4670-4678.

6 Bell JK, Mullen GE, Leifer CA, et al. Leucine-rich repeats and pathogen recognition in Toll-like receptors. Trends Immunol 2003;24:528-533.

7 Aliprantis AO, Yang RB, Mark MR, et al. Cell activation and apoptosis by bacterial lipoproteins through toll-like receptor-2. Science 1999;285: 736-739.

8 Takeuchi O, Hoshino K, Kawai T, et al. Differential roles of TLR2 and TLR4 in recognition of gramnegative and gram-positive bacterial cell wall components. Immunity 1999;11:443-451.

9 Schwandner R, Dziarski R, Wesche H, et al. Peptidoglycan- and lipoteichoic acid-induced cell activation is mediated by toll-like receptor 2. J Biol Chem 1999; 274:17406-17409.
10 Ye H, Arron JR, Lamothe B, et al. Distinct molecular mechanism for initiating TRAF6 signalling. Nature 2002;418:443-447.

11 Cirera I, Bauer TM, Navasa M, et al. Bacterial translocation of enteric organisms in patients with cirrhosis. J Hepatol 2001;34:32-37.

12 Chang CS, Chen GH, Lien HC, et al. Small intestine dysmotility and bacterial overgrowth in cirrhotic patients with spontaneous bacterial peritonitis. Hepatology 1998;28:1187-1190.

13 Guarner C, Runyon BA, Young S, et al. Intestinal bacterial overgrowth and bacterial translocation in cirrhotic rats with ascites. J Hepatol 1997;26:13721378.

14 Paik YH, Schwabe RF, Bataller R, et al. Toll-like receptor 4 mediates inflammatory signaling by bacterial lipopolysaccharide in human hepatic stellate cells. Hepatology 2003;37:1043-1055.

$15 \mathrm{Su}$ GL. Lipopolysaccharides in liver injury: molecular mechanisms of Kupffer cell activation. Am J Physiol Gastrointest Liver Physiol 2002;283:G256-G265.

16 Uesugi T, Froh M, Arteel GE, et al. Toll-like receptor 4 is involved in the mechanism of early alcohol-induced liver injury in mice. Hepatology 2001;34:101-108.

17 Riordan SM, Skinner N, Nagree A, et al. Peripheral blood mononuclear cell expression of toll-like receptors and relation to cytokine levels in cirrhosis. Hepatology 2003;37:1154-1164.

18 Brun P, Castagliuolo I, Pinzani M, et al. Exposure to bacterial cell wall products triggers an inflammatory phenotype in hepatic stellate cells. Am J Physiol Gastrointest Liver Physiol 2005;289:G571-G578.

19 Hayes MP, Zoon KC. Priming of human monocytes for enhanced lipopolysaccharide responses: expression of alpha interferon, interferon regulatory factors, and tumor necrosis factor. Infect Immun 1993;61: 3222-3227.

20 Romics Jr L, Dolganiuc A, Kodys K, et al. Selective priming to Toll-like receptor 4 (TLR4), not TLR2, ligands by $P$. acnes involves upregulation of $\mathrm{MD}-2$ in mice. Hepatology 2004;40:555-564.

21 Mochizuki S, Kobayashi M, Suzuki T, et al. Gammainterferon enhances expression of CD14/MyD88 and subsequent responsiveness to lipopolysaccharide from Actinobacillus actinomycetemcomitans in human gingival fibroblasts. J Periodontal Res 2004;39:333-343.

22 Tamai R, Sakuta T, Matsushita K, et al. Human gingival CD14(+) fibroblasts primed with gamma interferon increase production of interleukin-8 in response to lipopolysaccharide through upregulation of membrane CD14 and MyD88 mRNA expression. Infect Immun 2002;70:1272-1278.

23 Bosisio D, Polentarutti N, Sironi M, et al. Stimulation of toll-like receptor 4 expression in human mononuclear phagocytes by interferon-gamma: a molecular basis for priming and synergism with bacterial lipopolysaccharide. Blood 2002;99:3427-3431.

24 Khoruts A, Stahnke L, McClain CJ, et al. Circulating tumor necrosis factor, interleukin-1 and interleukin-6 concentrations in chronic alcoholic patients. Hepatology 1991;13:267-276.

25 Tilg H, Wilmer A, Vogel W, et al. Serum levels of cytokines in chronic liver diseases. Gastroenterology 1992;103:264-274.

26 Schnabl B, Choi YH, Olsen JC, et al. Immortal activated human hepatic stellate cells generated by ectopic telomerase expression. Lab Invest 2002;82:323-333. 
27 Schnabl B, Purbeck CA, Choi YH, et al. Replicative senescence of activated human hepatic stellate cells is accompanied by a pronounced inflammatory but less fibrogenic phenotype. Hepatology 2003;37:653-664.

28 Kweon YO, Paik YH, Schnabl B, et al. Gliotoxinmediated apoptosis of activated human hepatic stellate cells. J Hepatol 2003;39:38-46.

29 Schwabe RF, Schnabl B, Kweon YO, et al. CD40 activates NF-kappa B and c-Jun N-terminal kinase and enhances chemokine secretion on activated human hepatic stellate cells. J Immunol 2001;166:6812-6819.

30 Hellerbrand C, Jobin C, Iimuro Y, et al. Inhibition of NFkappaB in activated rat hepatic stellate cells by proteasome inhibitors and an IkappaB super-repressor. Hepatology 1998;27:1285-1295.

31 Hellerbrand C, Jobin C, Licato LL, et al. Cytokines induce NF-kappaB in activated but not in quiescent rat hepatic stellate cells. Am J Physiol 1998;275:G269-G278.

32 Pinzani M, Marra F. Cytokine receptors and signaling in hepatic stellate cells. Semin Liver Dis 2001;21:397-416.

33 Tateaki Y, Ogawa T, Kawada N, et al. Typing of hepatic nonparenchymal cells using fibulin-2 and cytoglobin/ STAP as liver fibrogenesis-related markers. Histochem Cell Biol 2004;122:41-49.
34 Dziarski R, Tapping RI, Tobias PS. Binding of bacterial peptidoglycan to CD14. J Biol Chem 1998;273: 8680-8690.

35 Gupta D, Kirkland TN, Viriyakosol S, et al. CD14 is a cell-activating receptor for bacterial peptidoglycan. J Biol Chem 1996;271:23310-23316.

36 Schroder NW, Morath S, Alexander C, et al. Lipoteichoic acid (LTA) of Streptococcus pneumoniae and Staphylococcus aureus activates immune cells via Toll-like receptor (TLR)-2, lipopolysaccharide-binding protein (LBP), and CD14, whereas TLR-4 and MD-2 are not involved. J Biol Chem 2003;278:15587-15594.

37 Heumann D, Barras C, Severin A, et al. Gram-positive cell walls stimulate synthesis of tumor necrosis factor alpha and interleukin-6 by human monocytes. Infect Immun 1994;62:2715-2721.

38 Faure E, Thomas L, Xu H, et al. Bacterial lipopolysaccharide and IFN-gamma induce Toll-like receptor 2 and Toll-like receptor 4 expression in human endothelial cells: role of NF-kappa B activation. J Immunol 2001;166:2018-2024.

39 Wald D, Qin J, Zhao Z, et al. SIGIRR, a negative regulator of Toll-like receptor-interleukin 1 receptor signaling. Nat Immunol 2003;4:920-927. 